\title{
FIBROTIC SEQUELAE IN PULMONARY PARACOCCIDIOIDOMYCOSIS: HISTOPATHOLOGICAL ASPECTS IN BALB/C MICE INFECTED WITH VIABLE AND NON-VIABLE Paracoccidioides brasiliensis PROPAGULES
}

\begin{abstract}
SUMMARY
Patients with paracoccidioidomycosis often present pulmonary fibrosis and exhibit important respiratory limitations. Based on an already established animal model, the contribution of viable and non-viable $P$. brasiliensis propagules to the development of fibrosis was investigated. BALB/c male mice, 4-6 weeks old were inoculated intranasally either with $4 \times 10^{6}$ viable conidia (Group I), or $6.5 \times 10^{6}$ fragmented yeast cells (Group II). Control animals received PBS. Six mice per period were sacrificed at 24, 48, 72h (initial) and 1, 2, 4, 8, 12 and 16 weeks post-challenge (late). Paraffin embedded lungs were sectioned and stained with H\&E, trichromic (Masson), reticulin and Grocott's. During the initial period PMNs influx was important in both groups and acute inflammation involving $34 \%$ to $45 \%$ of the lungs was noticed. Later on, mononuclear cells predominated. In group I, the inflammation progressed and granulomas were formed and by the $12^{\text {th }}$ week they fussed and became loose. Thick collagen I fibers were observed in $66.6 \%$ and $83.3 \%$ of the animals at 8 and 12 weeks, respectively. Collagen III, thick fibers became apparent in some animals at 4 weeks and by 12 weeks, $83 \%$ of them exhibited alterations in the organization and thickness of these elements. In group II mice, this pattern was different with stepwise decrease in the number of inflammatory foci and lack of granulomas. Although initially most animals in this group had minor alterations in thin collagen I fibers, they disappeared by the $4^{\text {th }}$ week. Results indicate that tissue response to fragmented yeast cells was transitory while viable conidia evoked a progressive inflammatory reaction leading to granuloma formation and to excess production and/or disarrangement of collagens I and III; the latter led to fibrosis.
\end{abstract}

KEYWORDS: Pulmonary fibrosis; Paracoccidioides brasiliensis; Viable conidia; Fragmented yeast cells; Histopathology; Collagen fibers; Granuloma formation.

\section{INTRODUCTION}

Paracoccidioidomycosis is a deep-seated systemic mycosis of importance in Latin America, including Colombia ${ }^{1,12,26}$. The disease, caused by the dimorphic fungus Paracoccidioides brasiliensis, is usually a chronic, progressive illness that involves several organs and systems, with predominance of the lungs ${ }^{18,19}$. The latter are presently considered as the primary site of the infection ${ }^{1,18}$. Effective treatment regimens are available ${ }^{25}$ to control the infectious process; nonetheless, most patients (60-80\%) develop fibrotic sequelae that may severely hamper respiratory functions and limit the patient well-being ${ }^{24,25,34}$.

In spite of the severe repercussions of fibrosis in this and in a number of other infectious and non-infectious disorders the mechanisms of tissue damage are incompletely understood ${ }^{11,21}$. Fibrosis appears to begin simultaneously with both the inflammatory process and the presence of leukocyte infiltrates; it then progresses and consolidates at the time of granuloma formation ${ }^{10,11,15,16,24}$. In the late stages of the inflammatory responses, an increase in the production of certain cytokines, especially those capable of promoting accumulation of connective tissue, is noticed $^{13,14,20}$. This results in structural and functional changes in the tissues, such as observed in other entities causing fibrosis ${ }^{13}$. In vitro experiments have demonstrated that tumor necrosis factor alfa (TNF- $\alpha$ ), transforming growth factor beta (TGF- $\beta$ ), gamma interferon (IFN- $\gamma$ ) and the interleukines IL-1 and IL-6, contribute towards the formation of tissue scarring leading to fibrosis ${ }^{8,14}$.

Our group has developed an experimental model of paracoccidioidomycosis by the intranasal inoculation of $P$. brasiliensis conidia, which reproduces several aspects of human disease, including changes in the reticular stroma of the lung's interstitium with formation of fibrotic scars $^{22,29}$. In a more recent study with this model, the sustained increase in lung tissue levels of TNF- $\alpha$ and TGF- $\beta$, was found to be associated with the production of granulomas and development of fibrosis ${ }^{11}$.

The above studies ${ }^{11,29}$ plus those conducted by KERR et al. ${ }^{15,16}$,

(1) Laboratorio de Patología, Clínica de las Vegas, Medellín, Colombia.

(2) Corporación para Investigaciones Biológicas (CIB), Medellín, Colombia.

(3) Facultad de Medicina, Universidad Pontificia Bolivariana, Medellín, Colombia.

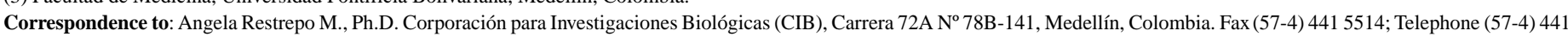
0855. Email: angelares@epm.net.co 


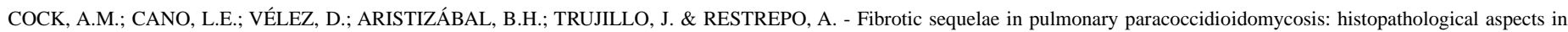
BALB/c mice infected with viable and non-viable Paracoccidioides brasiliensis propagules. Rev. Inst. Med. trop. S. Paulo, 42(2): 59-66, 2000.

LENZI et al. ${ }^{17}$, BURGER et al. ${ }^{2}$, SILVA ${ }^{31}$, SILVA \& FAZIOLI ${ }^{32}$ and SILVA et al. ${ }^{33}$ have described in detail not only the characteristics of the inflammatory response evoked by $P$. brasiliensis but also the constitutive elements of fibrosis (collagen fibers I and III, altered extracellular matrix components). Similar findings have been described in the lungs in autopsy $\operatorname{cases}^{34}$. Furthermore, in experimental studies it has been shown that the inoculation of yeast cell walls or derivatives of the same give rise to an intense inflammatory response $\mathrm{e}^{5,7,10}$. In spite of these findings, the roles played by the various types of inocula on the immune response, is far from clear.

This study explored the pulmonary response of mice inoculated intranasally with either viable $P$. brasiliensis conidia, propagules that had already been shown to induce fibrosis ${ }^{11,29}$ or fragmented yeast cells. The roles played by an active infection versus the continuous stimulus exerted by cell wall fragments in the development of the fibrotic sequelae, was investigated.

\section{MATERIALS AND METHODS}

\section{Animals}

Isogenic BALB/c male mice, 4-6 week old and weighing 18-20g, were used. Care was taken to use animals only within these categories as previous experiences (unreported) indicated their importance in the establishment of a progressive illness. The animals came from the CIB's breeding colony and were kept and fed under the conditions previously indicated $^{29}$. They were inoculated intranasally with either viable conidia (Group I) or disintegrated yeast cells (Group II), suspended in PBS. A control group (III), represented by animals inoculated only with PBS, was also included. Experiments required a total of 270 animals, inoculated as described below and sacrificed at various time intervals, early at 24 , 48, $72 \mathrm{~h}$ and late at 1, 2, 4, 8, 12, 16 weeks. In each period, 6 mice from each experimental group, as well as 4 non-inoculated control animals, were sacrificed for histopathological studies.

\section{Isolate and Inocula}

P. brasiliensis isolate (ATCC \# 60855) was passed through animals to restore virulence and then used for production of both conidia and yeast cells ${ }^{4}$. In group I, each mouse received an inoculum consisting of $4 \mathrm{X} 10^{6}$ viable conidia, suspended in $60 \mu \mathrm{L}$ of PBS. For group II, the inoculum consisted of $6.5 \times 10^{6}$ non-viable fragmented yeast cells, suspended in the same quantity of PBS. Control animals (Group III) received only PBS passed through glass wool (Pyrex fiber glass slivers, $8 \mu \mathrm{m}$, Corning glass works, Corning, New York, NY), such as done for separation of the conidia employed in group I mice ${ }^{28}$.

The inocula were prepared as described previously ${ }^{27,28}$. Briefly, conidia were obtained from mycelial cultures and filtered through glass wool. Ultrasonically-fragmented yeast cells were obtained by growing the fungus in tubes with the modified MacVeigh and Morton broth medium ${ }^{27}$, kept at $36^{\circ} \mathrm{C}$ with $5 \% \mathrm{CO}_{2}$ (Incubator NAPCO series 5400, Chicago, USA) under continuous shaking (Gyratory Shaker, model G2, New Brunswick Scientific Co, New Brunswick, NJ). When growth ensued, the contents of a tube were transferred to an Erlenmeyer containing $75 \mathrm{~mL}$ of fresh media and kept for 7 days, under the same conditions as the tubes. Sterility checking by microscopy and brain heart infusion (BHI) agar cultures, was done and when completed, a suspension containing $1.0 \times 10^{8}$ yeast cells per $\mathrm{mL}$ was subjected to ultrasonic vibration (Branson Sonifier Cell Disruptor \# 185, Branson Sonic Power Co, Smithkline Co, Swedesboro, NJ), for 20 cycles, 15 min each. Precautions were taken to avoid heating of the yeast suspension with the vial being kept under ice. Liberation of proteases during sonication was controlled by adding a cocktail of inhibitors (Pepsatin, Leupeptin, Phenylmethyl sulfonide fluoride, N-tosil-Lfenilalamine chloromethyl ketone, $(\alpha)$ p-methyl L lysine chloromethyl ketone), prepared at 0.1-0.2 $\mathrm{mM}$ concentrations (Sigma Chemical Co., St. Louis, USA). Upon sonication, viability testing was carried out with the ethidium bromidefluorescein stain to determine loss of viability ${ }^{3}$; microscopic observations were also done in order to ascertain that at least $90 \%$ of the yeast cells had been broken. Samples were then taken for dry weight determination in tared vials kept at $50{ }^{\circ} \mathrm{C}$ until dryness. The number of yeast cells subjected to sonic vibration was found to correspond to $56.17 \mathrm{mg} / 60 \mu \mathrm{L}$ of dry powder. This inoculum was distributed in small vials and kept at $4{ }^{\circ} \mathrm{C}$ until its use.

\section{Inoculation and Sacrifice}

Before proceeding to the inoculation, each animal was given $50 \mu \mathrm{L}$ of a mixture of ketamine (100mg) (Park-Davies \& Co., Ecuador) and xylazine (20mg) (Bayer S.A., Brasil) intramuscularly in order to achieve deep anesthesia ${ }^{29}$. The inoculum $(60 \mu \mathrm{L})$, either viable conidia, fragmented yeast cells or PBS, was administered intranasally, in two periods $8 \mathrm{~min}$ apart from each other, in order to facilitate complete inhalation of the inoculum.

At the chosen periods, animals were sacrificed by the intraperitoneal injection of $1.0 \mathrm{~mL}$ of $2.5 \%$ sodium penthotal.

To control inhalation, 3 mice were sacrificed immediately after inoculation. The lungs were homogenized in PBS with tissue grinders (Tissue Tearor, model 985-370, Biospec Products, Inc, Racine, WI) and plated by duplicate and in serial dilutions $\left(10^{-2}, 10^{-3}, 10^{-4}\right)$ on Mycocel agar (BBL, Beckton \& Dickinson, Cokeysville, MD) with $0.01 \%$ thiamine. Three weeks after incubation at $18^{\circ} \mathrm{C}$ (Precision Scientific low Temperature Incubator, Chicago, IL), CFU were determined.

\section{Samples and processing}

Upon death, the thoracic cavity of animals in groups I, II and III was opened and the right auricle sectioned; $10 \mathrm{~mL}$ of PBS were then injected directly on the heart in order to insuflate the lungs and withdraw any remaining blood. The left lung was removed, weighed and homogenized in $3.0 \mathrm{~mL}$ of PBS containing protease inhibitors; it was then used for CFU determination. The right lung was processed for histopathologic examinations. For CFU, the process was identical to the one described above. The number of CFU per organ was calculated as follows:

$\log _{10}$ [Weight of lung plus macerate's volume] X CFU/mL

\section{Histopathological Studies}

Once the right lung was resected, it was insuflated, fixed in $10 \%$ neutral formaldehyde in PBS, embedded in paraffin and cut in $5 \mu \mathrm{m}$ thick sections. Several staining procedures were employed to analyze 
the lung tissues, as follows: Hematoxilin and eosin, to determine the type and intensity of the inflammatory response; silver methenamine to detect the mycotic structures (conidia, yeast and fungal fragments); Gomori (silver reticulin) to visualize the presence and organization of reticulin type fibers and Masson thrichromic stain to detect collagen fibers, type I. In each case, the whole lung was divided in two sections, from apex to base, and the extension of the area corresponding to the inflammatory reaction was examined. The tissues were examined independently by two pathologists. Lungs of control animals served to establish absence of inflammation ( $0 \%)$; in infected animals, the extent of the inflammatory reaction was estimated according to the percentage of the tissue involved.

In this study we adopted Mitsuhashi's definition of fibrosis ${ }^{23}$, namely, a lung disorder associated to the progressive loss of pulmonary volume and of the functionality of the alveolus-capillary junction. Morphologically, fibrosis is characterized by an abnormal increase or an altered disposition of the connective tissue (collagens I, III). Our interpretations were based on the comparisons established between the infected and the control animals with the latter taken to represent the normal composition of the lung parenchyma.

The severity of the involvement was classified as previously suggested $^{29}$, with a slight modification consisting in studying the whole lung instead of a single region. Severity was graded as follows:

- Minor: Presence of isolated collagen I- and of fragmented reticulin fibers abnormally organized and with a condensed aspect. Both fibers would be localized in the center and around the inflammatory foci.

- Severe: Abundant, thick collagen I fibers. Additionally, an increased number of reticulin fibers that have altered their localization and organization would be present. As in the above case these fibers would appear around and in the interior of the granulomas.

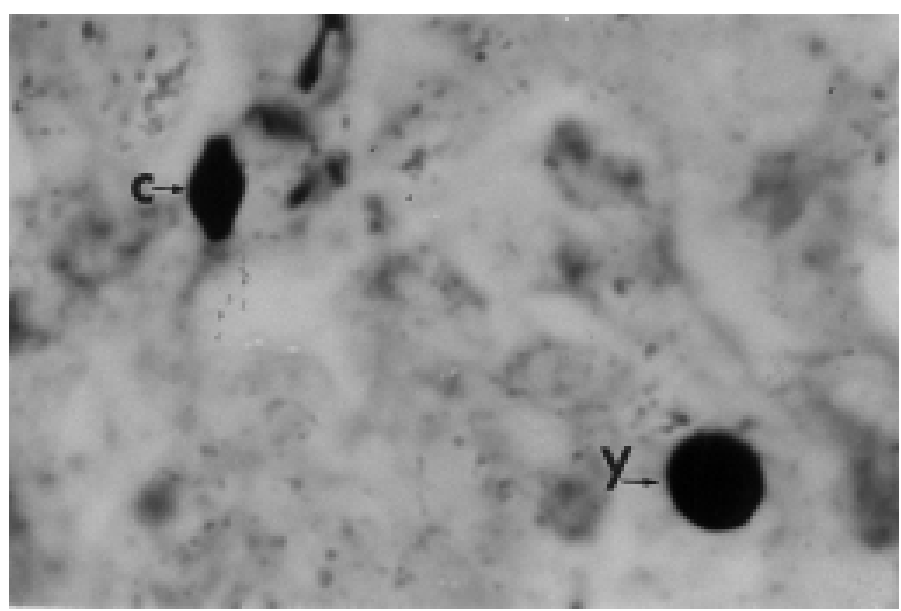

Fig. 1 - Presence of a conidium (C) and of a yeast cell (Y) in lung tissues, $24 \mathrm{~h}$ after inoculation with viable $P$. brasiliensis propagules. Gomori stain, 1,000X.
The granulomas were classified as compact and loose, according to MARIANO $^{21}$ and MONTENEGRO \& FRANCO $^{24}$. The former consisted of concentric rings of monocytes, lymphocytes and large mononuclear cells (epithelioid) arranged in palisade formation that occupy the center of the lesion. Giant cells were also present. Loose granulomas have undefined borders and are characterized by the presence of small groups of dispersed epithelioid cells as well as by a variable number of giant cells. Granulomas also had other components, namely, the inflammatory exudate composed of PMNs and fungal cells, in active multiplication.

\section{Statistical Analysis}

Statistical analyses were processed with the software Graph Pad, Prisma, (version 2.01, 1994). Statistical significance was determined by using Student's $t$ test analysis, and $\mathrm{p}<0.05$ considered significant

\section{RESULTS}

\section{Control (Group III) animals}

Mice inoculated intranasally with PBS had no alterations in their lungs. With the exception of a mild transitory inflammation (24-72h), infiltrates were absent and no changes were detected in the aspect or number of the collagen or reticulin fibers.

\section{Presence of Fungal Cells in the Lungs}

In the lungs of group I mice quantification with a $40 \mathrm{X}$ objective of the 10 microscopic fields, revealed that conidia as well as transforming propagules were present during the early periods (24-72h) (Fig.1). Later on, after one week, yeast cells were observed and increased in numbers with time post-challenge (Fig. 2). CFU corroborated fungal viability and showed increasing numbers ranging from 4.2 to $6.5 \log _{10}$ per lung up to week $12^{\text {th }}$ (data not shown). No intact fungal elements were observed in group II mice; however, in the Gomori-stained sections, the presence of fungal dust inside foamy histiocytes (Fig. 3) was observed regularly during the early stages post-challenge.

\section{Extension of the inflammatory reaction in the lungs of Groups I and II mice}

In group I animals and during the early stages post-infection (24, $48,72 \mathrm{~h}$ ), the inflammatory reaction occupied between $26.6 \%$ and $35.5 \%$ of the lung's area. From the $1^{\text {st }}$ to the $8^{\text {th }}$ week, there was a decrease in the above figures $(8.8 \%-14.2 \%)$. However, the infectious process reactivated later on and by the $12^{\text {th }}$ week, inflammation had extended to cover again $30.8 \%$ of the organ (Table 1 ).

In group II mice, the extent of the inflammatory reaction was somewhat higher during the early post-inoculation periods (40-48.3\%) but with no significant differences among the groups (Table 1). From the $1^{\text {st }}$ week on, these animals exhibited a progressive decrease in the extension of the inflammatory area and at the end of the experiment (weeks $12-16$ ), only a $3.3 \%$ to $3.0 \%$ of the pulmonary parenchyma was involved, respectively.

A comparison between the 2 groups revealed significant differences at 24 hours $(\mathrm{p}=0.01)$ and during the first 2 weeks post-challenge $(\mathrm{p}=0.001$ 


\section{Propagules observed in lung tissues in mice infected with $P$. brasiliensis conidia}

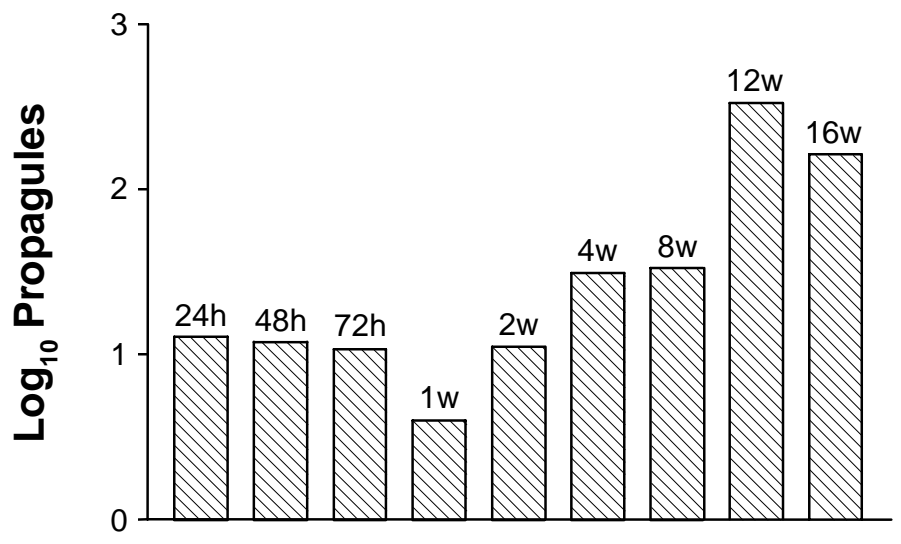

\section{Time post-challenge}

Fig. 2 - Determination of P. brasiliensis propagules in lung tissues, according to time postchallenge.

and 0.02 ), as well as by the $12^{\text {th }}$ and $16^{\text {th }}$ weeks, $\mathrm{p}=0.001$ and $\mathrm{p}=0.002$, respectively.

\section{Type of cells present in the infiltrate}

As shown in Table 2, in group I mice PMNs predominated during the first hours, $98.5 \%$ at $24 \mathrm{~h}$ and $75.8 \%$ at $72 \mathrm{~h}$. They decreased progressively in the following weeks; however, they did not disappear completely. Conversely, the mononuclear leukocytes were few (1-24\%) during the early periods but increased and reached high, stable levels, above $82 \%$, in the following weeks post-infection (data not shown).

In group II mice, cell distribution was similar to those of group I with only one difference, presence of PMNs; in the former group such cells disappeared after the $4^{\text {th }}$ week post-inoculation while in the latter they remained present all throughout the experiments. Significant differences were seen between the groups at 72 hours $(p=0.01), 2,4,8$, 12 and 16 weeks post-inoculation, with maximal $\mathrm{p}$ values at the $12^{\text {th }}$ week $(\mathrm{p}=0.0004)$ (Table 2).

\section{Granuloma formation}

Despite the similarities observed in the inflammatory response and the cell composition of the infiltrate, granulomas were formed only by group I animals. This structure became apparent only during the $1^{\text {st }}$ week and their number increased with time post-infection. During the following weeks and in the whole lung, the number of granulomas varied from 8 to 16 , with a peak at week 12 . Granulomas were compact when first formed but as shown in Fig. 4, they became loose with the progression of the infection.

\section{Histopathological findings}

In both groups of propagule-inoculated mice, the initial post-

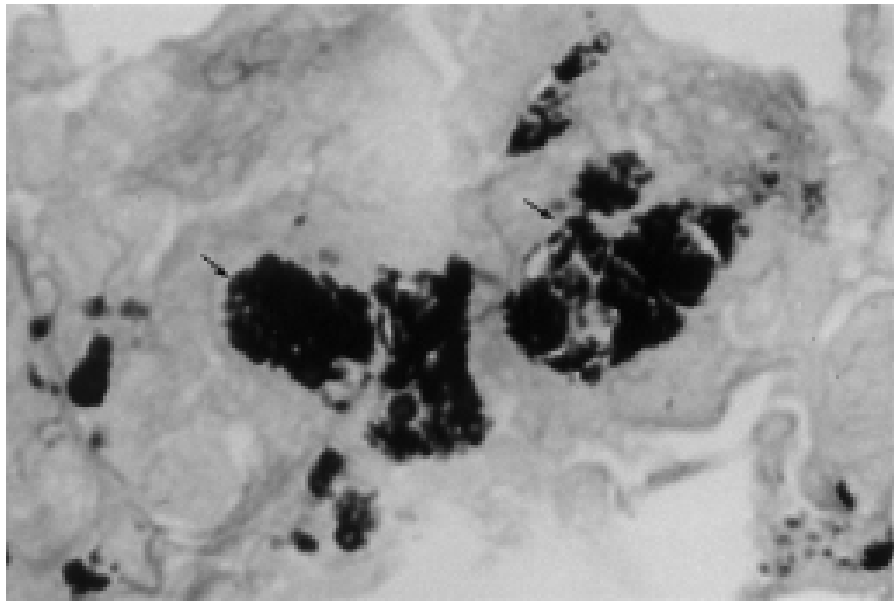

Fig. 3 - "Fungal dust" in the cytoplasm of a macrophage in the lung, 4 weeks post-challenge with fragmented $P$. brasiliensis yeast cells. Gomori stain, 400X.

Table 1

Extension of inflammatory reaction according to inoculum and time post-challenge

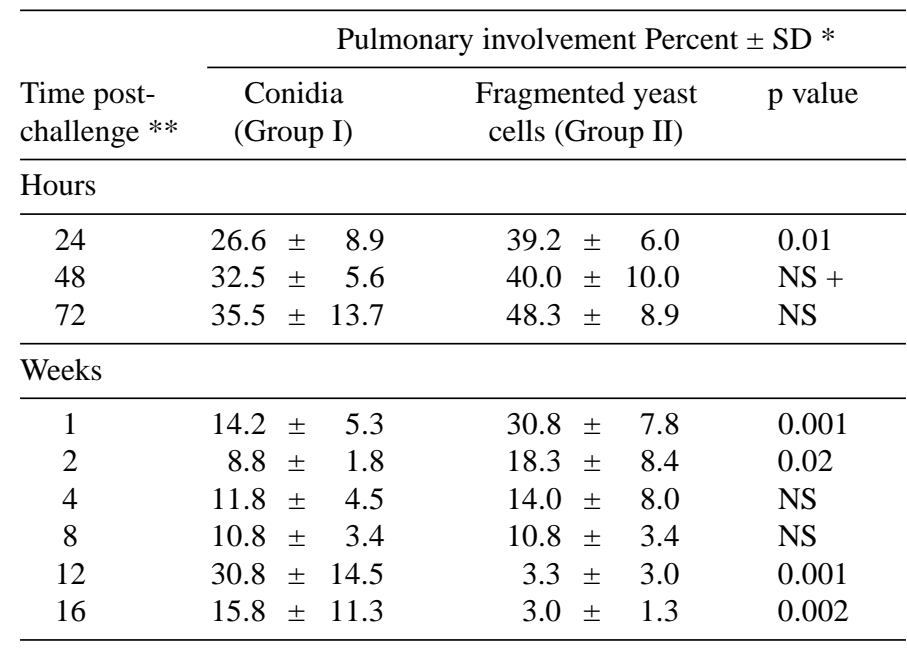

* The percentage was calculated by comparing control animals (no tissue reaction) to infected animals, and determining in the latter the proportion of the lung showing inflammatory reaction.

** Each experimental group consisted of 6 animals

+ NS: non-significant

challenge periods showed a bronchopneumonic, acute type of response. There were PMNs accumulations that fused with each other and constituted extensive, ill-defined masses. This reaction was more marked at the peribronchiolar level.

Group II animals showed a decrease of the acute inflammatory reaction during the $1^{\text {st }}$ week, when it changed and became a lymphohistio-plasmocytic infiltrate. At this period, there were few yeast cells located inside intra-alveolar macrophages. Group II mice also had macrophages characterized by a broad, foaming cytoplasm (Fig. 5); these cells contained ingested yeast fragments. 
At week 2 post-inoculation, differences became more pronounced as animals in group I but not those in group II, revealed granuloma formation. The granulomas had a concentric arrangement and exhibited epithelioid cells, lympho-histio-plasmocytic cells and Langhans giant cells. At this moment, the inflammatory reaction has diminished in group II animals, although the foamy macrophages continued to be present.

During the following weeks $\left(4-16^{\text {th }}\right)$, the inflammatory process progressed in the conidia-infected mice (group I) with granuloma formation, especially at the perivascular level and also, with persistence of the lympho-plasmocytic infiltrates. At week 12, when the granulomas were more abudant, they had lost their compact appearance and had become loose, fusing with each other. Yeast cells were numerous, in active multiplication, and appeared intermingled with PMNs, plasmocytes and fibroblasts. On the other hand, in animals of group II, only isolated, residual inflammatory foci could be found; macrophages exhibiting phagocytosed fungal residues were seen rarely. Eosinophils were not observed in either group.

\section{Collagen type I fibers}

In group I mice (Table 3), thin fibers were seen in 4/6 (66.6\%) of the animals after the first week post-infection, with a tendency to diminish at later stages. Thick fibers became apparent at 4 weeks in 1/6 animals $(16.6 \%)$ of the animals and their frequency increased thereafter so that by the $8^{\text {th }}$ and $12^{\text {th }}$ weeks, they were observed in $66.6 \%$ and $83.3 \%$ of the mice, respectively. At the end of the experiment, a third of the animals had severe involvement represented by thick collagen I fibers in the lung parenchyma, usually surrounding the granulomas. Fig 6 illustrates the presence of these fibers in a mouse inoculated with viable $P$. brasiliensis conidia.

The presence of thin collagen I fibers was also noticed at week 1 postinoculation in 5/6 (83.3\%) of the group II animals; however, these fibers

Table 2

Inflammatory cells in the lungs of animals (H \& E)

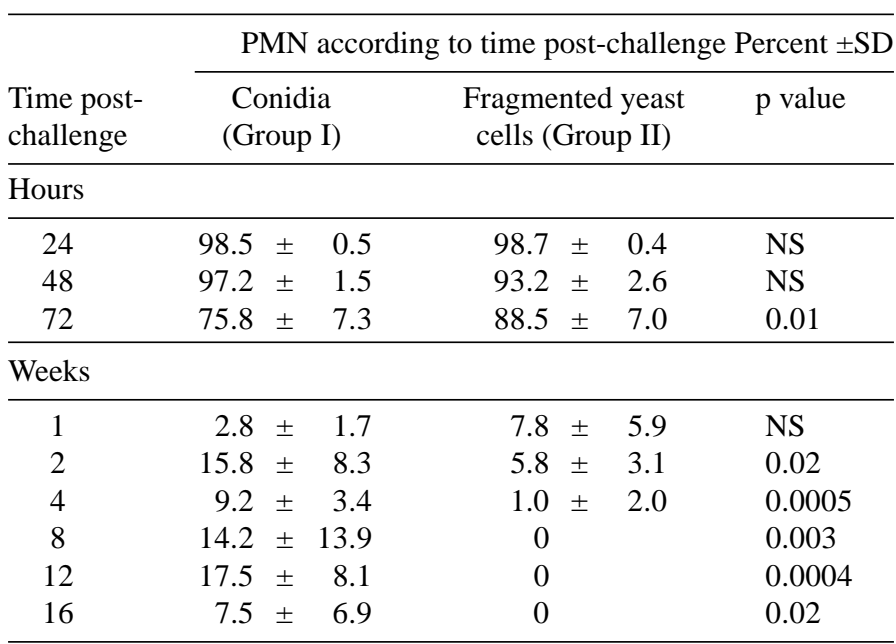

NS: non significant

*Each experimental group consisted of 6 animals

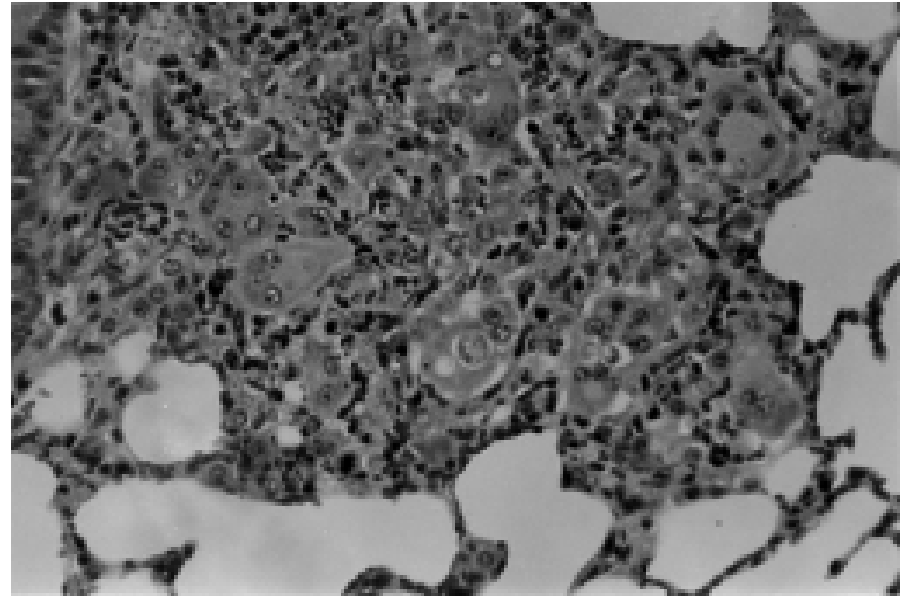

Fig. 4 - Loose granuloma in lung tissues, 2 weeks post-challenge with $P$. brasiliensis viable conidia. H\&E, 200X.

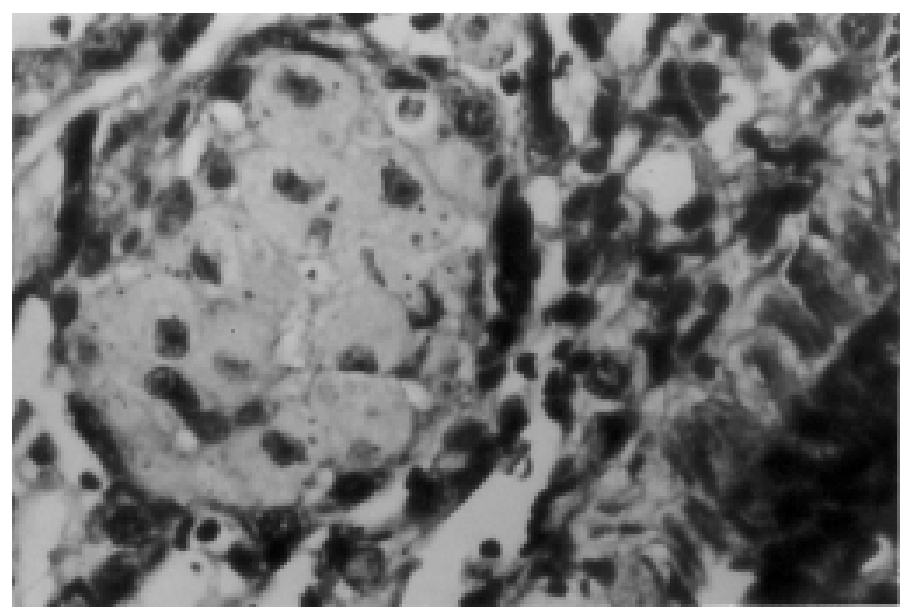

Fig. 5 - Accumulation of foamy histiocytes in a mouse inoculated with fragmented $P$. brasiliensis yeast cells. H\&E, 200X

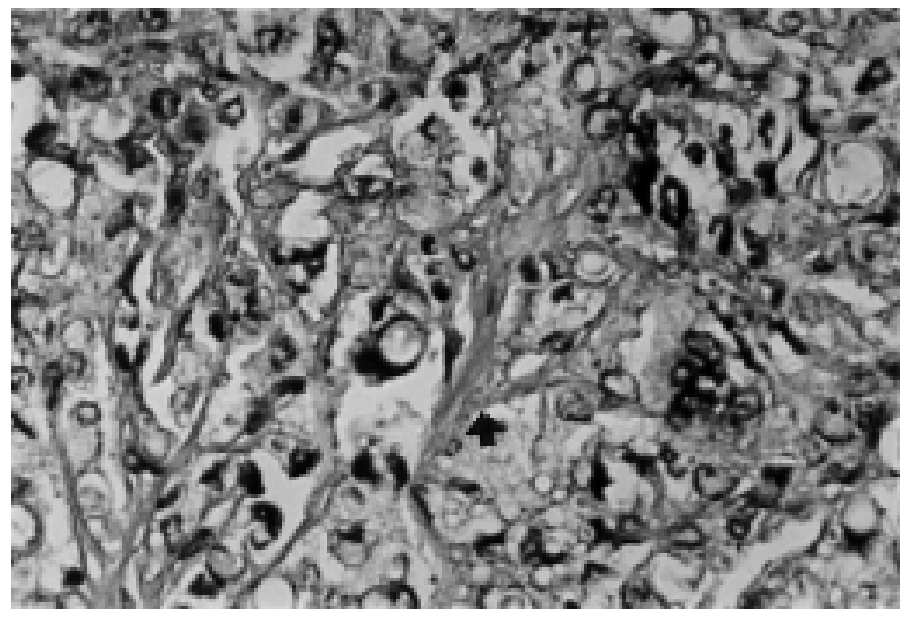

Fig. 6 - Thick collagen I fibers in lung tissues, 12 weeks post-challenge with $P$. brasiliensis viable conidia, Masson trichromic stain, 400X. 
Table 3

Collagen fibers type I (Trichromic Masson)

\begin{tabular}{|c|c|c|c|c|c|c|}
\hline \multirow{3}{*}{$\begin{array}{l}\text { Time post- } \\
\text { challenge }\end{array}$} & \multicolumn{6}{|c|}{ Number of animals inoculated with: } \\
\hline & \multicolumn{3}{|c|}{$\begin{array}{c}\text { Conidia } \\
(\text { Group I) }(\mathrm{n}=36)\end{array}$} & \multicolumn{3}{|c|}{$\begin{array}{c}\text { Fragmented yeast } \\
\text { cells (Group II) }(n=36)\end{array}$} \\
\hline & $\begin{array}{l}\text { No alte- } \\
\text { rations }\end{array}$ & Minor ${ }^{*}$ & Severe ${ }^{\bullet \bullet}$ & $\begin{array}{l}\text { No alte- } \\
\text { rations }\end{array}$ & Minor & Severe \\
\hline 1 & 2 & 4 & 0 & 1 & 5 & 0 \\
\hline 2 & 3 & 3 & 0 & 2 & 4 & 0 \\
\hline 4 & 3 & 2 & 1 & 5 & 1 & 0 \\
\hline 8 & 0 & 2 & 4 & 6 & 0 & 0 \\
\hline 12 & 0 & 1 & 5 & 6 & 0 & 0 \\
\hline 16 & 1 & 3 & 2 & 6 & 0 & 0 \\
\hline Total & $9^{+}$ & 15 & $12^{++}$ & $26^{+}$ & 10 & $0^{++}$ \\
\hline
\end{tabular}

-Minor: Presence of isolated collagen I organized abnormally and

with condensed appearance.

- Severe: abundant, thick collagen I fibers

$+<0.0006$

$++<0.021$

*Each experimental group consisted of 6 animals

diminished with time and disappeared after the $8^{\text {th }}$ week post-infection. No thick collagen I fibers were detected in this group (Table 3).

Statistically significant differences were observed between the groups concerning both the absence of fibrosis ( 9 vs. $26, \mathrm{p}<0.0006)$ and the presence of thick collagen fibers ( 12 vs. $0, \mathrm{p} \leq 0.021)$, heralding severe fibrosis.

\section{Reticulin fibers}

In both groups of mice, minor abnormalities in number and rearrangement of reticulin fibers was noticed only after the $1^{\text {st }}$ week postinfection. During the 1-4 week period, thin, disarranged elements were noticed in $1(17 \%)$ to $3(50 \%)$ of the animals. Later on, however, they disappeared. The thicker and grossly disarranged reticulin fibers corresponding to severe lung damage, were observed only in group I animals $(\mathrm{p} \leq 0.05)$. They became apparent in $1 / 6(17 \%)$ of the animals at 4 week and increased up to the $12^{\text {th }}$ week when $83.3 \%$ of the mice exhibited major alterations. Fig. 7 illustrates the corresponding histopathological aspect.

\section{DISCUSSION}

In this study, we observed the sequential histopathological changes that occurred as a result of the intranasal inoculation of either viable $P$. brasiliensis conidia or disintegrated yeast cells. As expected, progressive paracoccidioidomycosis became established with the former inoculum, as shown by the isolation of the fungus throughout the experimental period. The inflammatory process was, however, similar in both groups only that it was transient and acute with the fragmented yeast cells. Consequently the progressive histopathological changes observed in group I mice can be attributed to the infection and confirm previous findings concerning the tissue responses elicited by the fungal process ${ }^{11,29}$.

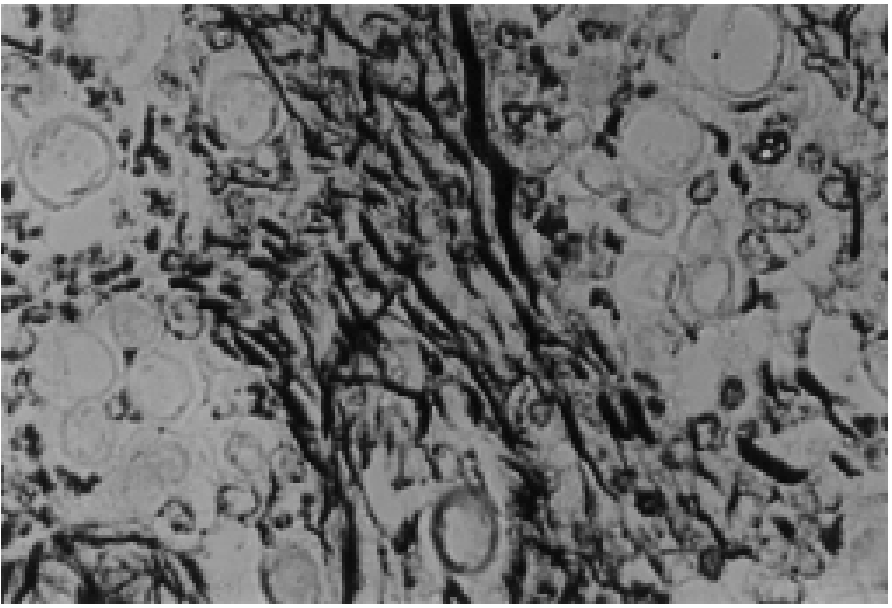

Fig. 7 - Thick and disorganized reticulin fibers in lung tissues after 12 weeks post-challenge with $P$. brasiliensis viable conidia. Reticulin stain, $400 \mathrm{X}$

Other authors who have previoulsy induced experimental infections with viable yeast cells, have found a similar pattern of response to the one observed with conidia ${ }^{2,5,6}$. Initially there is PMNs afflux, which then changes towards a lympho-histo-plasmocytic infiltrate and ending with granuloma formation. On the other hand, use of purified fungal components, such as lipids and polysaccharides, has shown to induce only a limited, non-progressive tissue response $\mathrm{e}^{10,31,32,33}$.

In this study the histopathological comparison between conidiainfected mice and animals inoculated with fragmented yeast cells, revealed two important differences. One was the persistence during the experimental period of low but constant numbers of PMNs in the former group and their tendency to disappear in the latter. It has been shown that in tissues, PMNs tend to surround yeast cells and probably, destroy them by liberation of their granules' contents ${ }^{2}$. SILVA et al. ${ }^{33}$ have suggested that during the early stages of the host-parasite interaction, massive infiltration by PMNs, as well as their presence around the suppurative region of the granulomas, during the latter phase, suggest that they have an important role in defense, and that they kill the fungus. This has been demonstrated in tuberculosis, a disease where PMNs play a significant role in liquefying the granulomas ${ }^{21}$.

Whether persistence of PMNs around the inflammatory foci could be correlated to continued tissue damage in chronic forms of paracoccidioidomycosis, remains to be shown.

The second important difference between the two groups, lied in the formation of granulomas in all conidia-infected mice and the absence of these structures in animals receiving fragmented yeast cells. The latter finding, however, does not agree with the experiences of SILVA ${ }^{31}$, SILVA \& FAZIOLI ${ }^{32}$, SILVA et al. ${ }^{33}$, FIGUEIREDO et $a l .{ }^{10}$ and DEFAVERI et $a l .^{6,7}$, who observed granulomas in mice and rats inoculated by the intraperitoneal route with a variety of cell wall fragments and cellular products (glucan, lipids, polysaccharides). None of these authors, however, used air-borne models or viable conidia nor did they report on the presence of the most essential element of the granuloma, the epithelioid cell ${ }^{21}$. It has been noticed that different routes of inoculation 


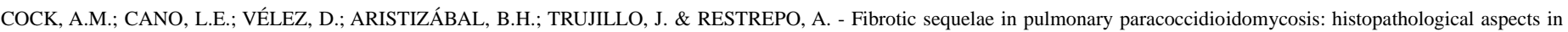
BALB/c mice infected with viable and non-viable Paracoccidioides brasiliensis propagules. Rev. Inst. Med. trop. S. Paulo, 42(2): 59-66, 2000.

may, at times, give rise to different host responses and this could be another explanation for the observed differences ${ }^{6}$. Our data indicate that fibrosis is the result of an active, progressive pulmonary infection in which the inflammatory response is strong and formation of granuloma takes place.

Fungal cell wall components tend to remain in the host's tissues for some time and consequently, they continue to stimulate the tissue's immune responses to produce the characteristic chronic inflammatory reaction $^{2,10,11,31,32}$. Nonetheless, it has been shown that the presence of $\alpha$ glucan in the yeast cells contributes to the virulence of the fungus as this component is slowly degraded by the host ${ }^{30}$. The in situ stimulus exerted by fungal components, was clearly illustrated in chromoblastomycosis, a disorder in which persistence of fungal cells in affected tissues, was the most important pathological factor involved in the progressive inflammatory reaction, as well as in the subsequent fibrosis 9

The clue element in the development of fibrosis appears to be the granuloma. Although this formation is recognized as the most potent defense mechanism against $P$. brasiliensis $^{12,24}$, it also appears to damage the host because it is in their surroundings that fibrosis becomes organized $^{2,17,21,24}$. This dual function could be related to the type of granuloma being formed; when they are compact, as is the case when they first appear, they are capable of restraining fungal multiplication such as shown by the presence of only a few yeast cells in these experiments. On the other hand, when granulomas become loose, their protective function ceases to operate and yeast cells increase in number. At this stage of the host-parasite interaction, granulomas may only serve to perpetuate the tissue's inflammatory responses with fibrosis representing its final consequence. As indicated by KERR et al..$^{16}$, the occurrence of recent granulomas with older ones, implies that this process does not eliminate the fungus nor is it capable of limiting fungal multiplication.

As shown, group II animals had no granulomas nor did they present thick reticulin or collagen fibers type I . On the contrary, most (83\%) mice infected with viable conidia, exhibited both elements. These findings tend to indicate that alterations in number and arrangement of collagen I and reticulin fibers, both of which centered around the loose granulomas, constitute essential elements in the transformation of the lung's tissues into a consolidated structure, unable to perform the normally free gaseous interchanges ${ }^{15,16,17,34}$.

Actually, granulomatous inflammation is the pathological substrate for many infectious microorganisms (tuberculosis, leprosy) as well as for non-infectious irritating agents (talc, berillium). In tissues, all these agents are capable of evoking this type of reaction, which, in turn, prompts excess accumulation of connective tissue resulting in structural and functional alterations of the parenchyma ${ }^{13,21}$.

Much remains to be done before the genesis of the fibrotic process in paracoccidioidomycosis is understood; however, the possibility offered by the mouse model here reported may contribute to designing new, more far reaching experiments.

\section{RESUMO}

Sequela fibrótica na paracoccidioidomicose pulmonar: aspectos
histopatológicos em camundongos BALB/c infectados com
propágulos viáveis e não viáveis do Paracoccidioides brasiliensis

Pacientes com paracoccidioidomicose apresentam, algumas vezes, fibrose pulmonar e exibem limitações respiratórias importantes. Baseados num modelo animal já estabelecido da micose, estudamos a possível contribuição de propágulos viáveis e não viáveis do Paracoccidioides brasiliensis ao desenvolvimento da fibrose. Assim, camundongos BALB/ c, machos de 4 a 6 semanas de idade, foram inoculados intranasalmente com 4 x $10^{6}$ conídios viáveis (Grupo I), ou com 6,5 x $10^{6}$ fragmentos não viáveis de células leveduriformes (Grupo II). Animais controles (Grupo III) receberam unicamente PBS. Seis camundongos por período foram sacrificados 24, 48, 72h (inicial) e 1, 2, 4, 8, 12 e 16 semanas pós-inoculação (tardio). Os pulmões dos animais foram fixados, incluidos em parafina, cortados e corados com H \& E, Tricrômico (Masson), reticulina e Grocott. Durante o período inicial houve afluxo importante de PMNs em ambos os grupos I e II, e a inflamação aguda comprometeu entre 34 a $45 \%$ dos pulmões. Depois, foram as células mononucleares as que predominaram. No grupo I, a inflamação progrediu e formaram-se granulomas os quais, às 12 semanas, ficaram confluentes e frouxos. Adicionalmente, se observaram fibras de colágeno tipo I muito densas em 66,6\% e 83,3\% dos animais após 8 e 12 semanas, respectivamente. As fibras do colágeno tipo III foram observadas nos animais a partir das 4 semanas pós-infecção, e 83\% deles exibiram, às 12 semanas, alterações na sua distribuição e organização. Nos animais do grupo II o padrão foi diferente, pois mostraram diminuição gradual no número de focos inflamatórios e não houve formação dos granulomas. Embora animais deste grupo tivessem no período inicial pequenas alterações nas fibras de colágeno tipo I, estas desapareceram por volta da 4 semana. Os resultados indicam que a resposta tissular aos fragmentos de leveduras foi transitória, enquanto que os conídios induzem resposta inflamatória progressiva permitindo a formação de granuloma e um excesso na produção e desorganização dos colágenos I e III, permitindo finalmente a fibrose.

\section{ACKNOWLEDGEMENTS}

This study was supported by a grant from COLCIENCIAS, Santafé de Bogotá, Colombia, Project N ${ }^{\circ}$ 2213-04-072-95 and the Corporación para Investigaciones Biológicas (CIB), Medellín, Colombia.

Sincere appreciation is expressed to the following persons:

Dr. John R. Graybill, University of Texas, Health Science Center, San Antonio, Texas, for his cooperation in procuring the inoculation chambers and some reagents required for our work.

Dr. Liliana Franco for her active and devoted participation during the early stages of this work.

Drs. Susana Restrepo and Maria del Pilar Perez for their expert counseling on histopathological matters. 


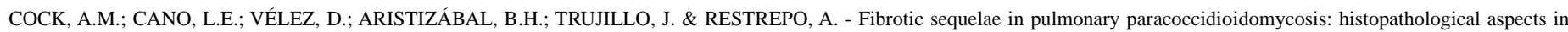
BALB/c mice infected with viable and non-viable Paracoccidioides brasiliensis propagules. Rev. Inst. Med. trop. S. Paulo, 42(2): 59-66, 2000.

\section{REFERENCES}

1. BRUMMER, E.; CASTAÑEDA, E. \& RESTREPO, A. - Paracoccidioidomycosis: an update. Clin. Microbiol. Rev., 6: 89-117, 1993.

2. BURGER, E.; MIYAJI; M.; SANO, A. et al. - Histopathology of paracoccidioidomycosis infection in athymic and euthymic mice: a sequential study. Amer. J. trop. Med. Hyg., 55: 235-242, 1996.

3. CALICH, V.L.; PURCHIO, A. \& PAULA, C.R. - A new fluorescent viability test for fungal cells. Mycopathologia (Den Haag), 66: 175-177, 1978.

4. CANO, L.E. - Paracoccidioidomicose pulmonar experimental: caracterização do modelo de infecção intratraqueal em camundongos resistentes e susceptíveis. Participação do IFN- $\gamma$, células $\mathbf{T ~}_{\mathbf{C D}_{4}} \mathbf{e} \mathbf{C D}_{8}$ na resistência ao fungo. São Paulo, 1995. (Tese de Doutoramento - Instituto de Ciências Biomédicas da Universidade de São Paulo).

5. COELHO, K.I.R.; DEFAVERI, J.; REZKALLAH-IWASSO, M.T. \& PERAÇOLI, M.T.S. -Experimental paracoccidioidomycosis. In: FRANCO, M.; LACAZ, C.S.; RESTREPO-MORENO, A. \& DEL NEGRO, G.- Paracoccidioidomycosis. Boca Raton, CRC Press, 1994. p. 87-107.

6. DEFAVERI, J.; REZKALLAH-IWASSO, M.T. \& FRANCO, M. - Experimental pulmonary paraccocidioidomycosis in mice: morphology and correlation of lesions with humoral and cellular immune responses. Mycopathologia (Den Haag), 77: 3$11,1982$.

7. DEFAVERI, J.; MARTIN, L.C. \& FRANCO, M. - Histological and ultrastructural study of the inflammation evoked by Paracoccidioides brasiliensis antigen in previously immunized mice. Mycopathologia (Den Haag), 105: 53-58, 1989.

8. ELIAS, J.A.; FREUNDLICH, J.B.; KERR, J.A. \& ROSENBLOOM, J. - Cytokine networks in the regulation of inflammation and fibrosis in the lung. Chest, 97: 14391445,1990

9. ESTERRE, P.; PEYROL, S.; SAINTE-MARIE, D.; PRADINAUD, R. \& GRIMAUD, J.A. - Granulomatous reaction and tissue remodelling in the cutaneous lesion of chromomycosis. Virchows Arch. Abt. A. path. Anat., 422: 285-291, 1993.

10. FIGUEIREIDO, F.; SILVA, C.L.M. \& ROSSI, M.A. - Participation of Paracoccidioides brasiliensis lipids and polysaccharides in the evolution of granulomas. Braz. J. med. biol. Res., 19: 651-653, 1986.

11. FRANCO, L.; NAJVAR, L.; GOMEZ, B.L. et al. - Experimental pulmonary fibrosis induced by Paracoccidioides brasiliensis conidia: measurement of local host responses. Amer. J. trop. Med. Hyg., 58: 424-430, 1998.

12. FRANCO, M.F.; MENDES, R.P.; MOSCARDI-BACCHI, M.; REZKALLAH-IWASSO, M.T. \& MONTENEGRO, M.R. - Paracoccidioidomycosis. Bailliére's clin. trop. Med. comm. Dis., 4: 185-220, 1989.

13. FRIEDMAN, S.L. - The cellular basis of hepatic fibrosis. New Engl. J. Med., 328: 1828-1835,1993.

14. HUNNINGHAKE, G.W. \& KALICA, A.R. - Approaches to the treatment of pulmonary fibrosis. Amer. J. respir. crit. Care Med., 151: 915-918, 1995.

15. KERR, I.B.; OLIVEIRA, P.C. \& LENZI, H.L. - Connective matrix organization in chronic granulomas of experimental paracoccidioidomycosis. Mycopathologia (Den Haag), 103: $11-20,1988$.

16. KERR, I.B.; ARARIPE, J.R.; OLIVEIRA, P.C. \& LENZI, H.L. - Paracoccidioidomycosis: a sequential histopathologic study of lesions in experimentally-infected rats. Rev. Inst. Med. trop. S. Paulo, 30: 336-350, 1988.
17. LENZI, H.L.; CALICH, V.L.G.; MIYAJI, M. et.al. - Fibrosis patterns of lesions developed by athymic and euthymic mice infected with Paracoccidioides brasiliensis. Braz. J. med. biol. Res., 27: 2301-2308, 1994.

18. LONDERO, A.T. - Paracoccidioidomicose: formas clínicas, manifestações pulmonares e diagnóstico. J. Pneumol., 12: 41-60, 1986.

19. LONDERO, A.T. \& RAMOS, C.D. - Paracoccidioidomicose: estudo clínico-micológico de 260 casos observados no interior do Estado do Rio Grande do Sul. J. Pneumol., 16: 129-132, 1990.

20. MAQUART, F.X.; GILLERY, P.; KALIS, B. \& BOREL, J.P. - Cytokines and fibrosis. Europ. J. Derm., 4: 91-97, 1994.

21. MARIANO, M. - The experimental granuloma. A hypothesis to explain the persistence of the lesion. Rev. Inst. Med. trop. S. Paulo, 37: 161-176, 1995.

22. MCEWEN, J.G.; BEDOYA, V.; PATIÑO, M.M.; SALAZAR, M.E. \& RESTREPO, A. Experimental murine paracoccidioidomycosis induced by the inhalation of conidia. J. med. vet. Mycol. , 25: 165-175, 1987.

23. MITSUHASHI, T.; SHIMAZAKI, M.; CHANOKI, Y. et al. - Experimental pulmonary fibrosis induced by trisodium citrate and acid-citrate-dextrose. Exp. molec. Path., 42: 261-270, 1985.

24. MONTENEGRO, M.R. \& FRANCO, M. - Pathology. In: FRANCO, M.; LACAZ, C.S.; RESTREPO-MORENO, A. \& DEL NEGRO, G. Paracoccidioidomycosis. Boca Raton, CRC Press, 1994. p. 131-150.

25. NARANJO, M.S.; TRUJILlO, M.; MÚNERA, M.I. et.al. - Treatment of paracoccidioidomycosis with itraconazole. J. med. vet. Mycol., 28: 67-76, 1990.

26. NEGRONI, R. - Paracoccidioidomycosis (South American Blastomycosis, Lutz Mycosis). Int. J. Derm., 32: 847-859, 1993.

27. RESTREPO, A. \& JIMÉNEZ, B.E. - Growth of Paracoccidioides brasiliensis yeast phase in a chemically defined culture medium. J. clin. Microbiol., 12: 279-281, 1980.

28. RESTREPO, A.; SALAZAR, M.E.; CANO, L.E. \& PATIÑO, M.M. - A technique to collect and dislodge conidia produced by Paracoccidioides brasiliensis mycelial form. J. med. vet. Mycol., 24: 245-248, 1986.

29. RESTREPO, S.; TOBÓN, A.M.; TRUJILLO, J. \& RESTREPO, A. - Development of pulmonary fibrosis in mice during infection with Paracoccidioides brasiliensis conidia. J. med. vet. Mycol., 30: 173-184, 1992.

30. SAN BLAS, G. - The cell wall of fungal human pathogens: its possible role in the hostparasite relationships. Mycopathologia (Den Haag), 79: 159-184, 1982.

31. SILVA, C.L. - Granulomatous reaction induced by lipids isolated from Paracoccidioides brasiliensis. Trans. roy. Soc. trop. Med. Hyg., 79: 70-73, 1985.

32. SILVA, C.L. \& FAZIOLI, R. - A Paracoccidioides brasiliensis polysaccharide having granuloma-inducing, toxic and macrophage-stimulating activity. J. gen. Microbiol. 131: $1497-1515,1985$.

33. SILVA, C.L.; ALVES, L.M.C.C. \& FIGUEIREDO, F. - Involvement of cell-wall glucans in the genesis and persistence of the inflammatory reaction caused by the fungus Paracoccidioides brasiliensis. Microbiology, 140: 1189-1194, 1994.

34. TUDER, R.M.; EL IBRAHIM, R.; GODOY, C.E. \& DE BRITO, T. - Pathology of the human pulmonary paracoccidioidomycosis. Mycopathologia (Den Haag), 92: 179$188,1985$.

Received: 30 August 1999

Accepted: 09 March 2000 